\title{
Are Methodist Church bereavement ritual's sufficient for its black African members?: A qualitative analysis of a church in Mamelodi, South Africa
}

\author{
Rev. Jacob Mokhutso \\ University of the Free State \\ Biblical and Religious Studies \\ Faculty: Theology and Religion \\ P.O. Box 339, Bloemfontein 9300 \\ Republic of South Africa \\ E-mail: MokhutsoJ@ufs.ac.za \\ Doi: https://doi.org/10.46222/pharosjot.102.021
}

\begin{abstract}
A phenomenon is observed during bereavement amongst the Methodists residing in Mamelodi, Pretoria. Families often seek the churches to be involved, and this normally entails offering pastoral care and leading Christian bereavement rituals. Ironically and at the same time, the same families require, perform, and observe African traditional bereavement rituals. This observation raises the question: Are the Methodist Church's bereavement rituals conducted during bereavement insufficient? Does this phenomenon mean that what the Methodist Church offers its members is inadequate/lacking to offer healing and comfort to the bereaved families during their time of grief? A qualitative approach and interviews were used as a data-collection method within a (descriptive-explorative) case study design. Many African scholars acknowledge and have written at length about the significance of bereavement rituals among African communities. This research found that it is not a matter of being sufficient or insufficient, but rather that there is a deficit in teachings regarding what these rituals mean. The Methodist Church's rituals are devoid of the African-ness, which embraces the culture and identity of the Black African members to whom they are ministering. As much as they are appreciated, they run short of embracing their identity as African people. Some participants interviewed did acknowledge that the Methodist Churches' Christian bereavement rituals are sufficient for them but this is not the case for all adherents of the faith.
\end{abstract}

Keywords: Methodist Church, African traditional religion, bereavement, rituals, sufficient.

\section{Introduction}

Bereavement rituals are of great significance in African communities. Although these rituals may differ in the various ethnic groups, a common factor in Africa is their great significance. These bereavement rituals reflect societal belief systems and identity.

This significance also applies in the Christian faith, as they demonstrate the teachings and doctrines of different Christian traditions. Furthermore, all Christians celebrate funeral rites as their way of worshipping, praising, and giving thanksgiving to God for the gift of a life which has now been returned to God, the author of life and the hope of the just (Order of Christian Funeral 1988:1). Bereavement rituals exemplify both the Church and African traditional communities; they also bring healing, comfort and offers closure to the bereaved. Zungu (2011:7) state that adherence to religious instruction provides solace for bereaved family members, as the funeral preparations and the rituals that go with them provide closure. Nelson Mandela was a 
distinguished politician with Methodist roots and he addressed the annual conference in a 1994, praising the work of the church throughout the era of white minority-rule (Mandela, 2013). The Methodist movement, is a group of historically related denominations of Protestant Christianity which derived their doctrine of practice and belief from the life and teachings of John Wesley. It is this denomination which is looked at in this limited study.

While the Methodist Church in Mamelodi in Pretoria, South Africa, may be asked to assist the bereaved families in their grief, the families often additionally require African traditional bereavement rituals. Some families do so concurrently with the church's bereavement rituals, such as when a clergyman leads the corpse out of the hearse, church, or bereaved home into the hearse or cemetery reciting texts from the Holy Scriptures, especially those speaking about the promise of life evermore and the Resurrection. Other families may often require family clan praises to be said, or when a chosen member of the family speaks to the deceased's body it is taken to either the church or the cemetery. This raises a question: Are the bereavement rituals offered by the Methodist Church sufficient for its members? Surely, if the rituals offered by the church were sufficient, its members would be content with what the Methodist Church does for them during their sad time of bereavement. These views encompass the main question of this study: What does this study then investigate?

There is no doubt that scholars such as Ntombana (2015:105) correctly point out that some mainline or former missionary churches such as the Methodist Church of Southern Africa do not have any guidelines or conversations on the topics of African Traditional bereavement rituals. Therefore, this study has attempted to answer the following (secondary/subsidiary) research questions: What is the significance of African traditional bereavement rituals? What is the importance of Christian bereavement rituals? Why do members of the Methodist Church prefer to combine these diverse bereavement rituals?

\section{The Methodist belief on death and the Africa worldview and understanding of death}

One core reality about the subject of death is that it is a universal human experience (Makgahlela, 2016:1). Death is not a religious or cultural occurrence; it affects all living creatures, including human beings (Biwul, 1978:1).

\section{Christian understanding of death}

Although Christians worldwide may differ in doctrine, their common factor is that in the face of death, the church confidently proclaims that God has created each person for eternal life and that Jesus, the Son of God, by his death and glorious Resurrection, broke the chains of sin and death that bound humanity (Order of Christian Funerals, 1988:1).

Keating (2002:2) defines death from a Christian theological perspective as the time that the person's body is separated from their soul (the immaterial part of humans). Keating (2002:2) further states that from the Christian perspective, death is not the end of life. Instead, death is a transfer from one state of being to another, as the Bible teaches: "Just as people are destined to die once, and after that to face judgement" (Hebrews 9:27). This means that human beings will one day be resurrected from the dead and be judged according to their deeds and their relationship with God through Jesus Christ who is the redeemer of humanity and to whom we atone for our many transgressions (Nicolaides, AC \& Willimus, 2019).

Furthermore, through its funeral rites, the church commends the dead to God's merciful love and pleads for the forgiveness of their sins (Order of Christian Funerals, 1988:1; Thus, the Christian perspective, the theology of death is embedded in the life, death, and Resurrection of Jesus Christ 
in all denominations starting with the early Orthodox Church (Nicolaides, 2014; 2005).McGrath (2001:404) further posits that, to Christian believers, the Resurrection of Jesus serves an additional function within Christian theology. It establishes and undergirds Christian hope. This has both soteriological and eschatological implications. At the eschatological level, it gives both foundation and substance to the Christian hope of eternal life. At the rite of final commendation and farewell, the community acknowledges the reality of separation and commends the deceased to God. In this way, it recognizes the spiritual bond between the living and the dead and proclaims its belief that all the faithful will be raised and reunited in the new heavens and a new earth, where death will be no more (Order of Christian Funerals, 1988:1).

\section{The Methodist Church's understanding of death}

The Methodist Church of Southern Africa, like many other Christian traditions, has a theology of death. Methodists believe that life is eternal and that one can look forward to life with God after death, although they hold varied beliefs about the afterlife. They regard the funeral service as an occasion to express their grief, celebrate the life of the deceased and confirm their faith but is all however from a western perspective (Forster \& Bentley, 2008).

Ketshabile (2012:86) posits that the current Methodist burial rites originate from John Wesley's Order of the Burial of the Dead, written in 1784. This document has been the mother of all Methodist liturgies across the globe. Ketshabile (2012:88) further states that the theological ideas of John and Charles Wesley were the principal sources for understanding Methodist views on life and death. Puritan theology, which was popular in the nineteenth century, mainly influenced the Order of the Burial of the Dead (Ketshabile, 2012:88). The theology spread what was termed 'good death' or 'holy dying' (Ketshabile, 2012:98). For the Puritans who influenced Wesley's theology, death was a form of conflict of faith, as well as an opportunity to glorify God. For John Wesley, death was an opportunity to build others confidence in the Lord (Ketshabile, 2012:101). This was reflected by a uniquely Methodist tradition of singing hymns at funerals (Ketshabile, 2012:111). However, despite this historical and theological background that has shaped the theology of Methodists worldwide, the Methodist Church of Southern Africa is still trying to find itself regarding its theology of death. Ketshabile (2012:125) notes, that burial liturgies developed by Methodists in Britain have a distinct disadvantage as they are not uniformly applied.

Kumalo (2018:13) further elaborates on Ketshabile's (2012:125) sentiments and suggests that there is confusion when different liturgies are used at different funerals. According to Kumalo (2018:13)

The MCSA adopts these liturgies without scrutinizing them for purposes of contextualizing them for the African context...the MCSA must take cognizance of the absence of the African worldview in the rubrics of their liturgies. I think it is a demonstration that as a church, we have reached a point where we need to reflect deeply on our theologies, especially around the reality of death. Demode assumptions and theological beliefs have to be revised, and developments brought about by contextual dynamics, new beliefs and practices have to be considered.

Baloyi and Makobe - Rabothata (2013:1) state that African epistemology views death as a transition from the visible to the invisible ontology where the spirit, the essence of the person is not destroyed but moves to live in the spirit ancestors realm of the dead. Therefore, for African people, rituals are very important for a full transition to occur. Africans take this process very seriously, so that the transition can take place appropriately. Mbiti (1993:185) states that, during a time of bereavement, the living do not want to offend them, either by failure to fulfil any obligations due to them or by acting in a way which is contrary to the pattern of life which had 
been acceptable to them or there will be dire consequences referring to what happens to the deceased (Baloyi \& Makobe-Rabothata, 2013:1). Baloyi and Makobe -Rabothata (2013:236 citing Mbiti, 1990, Ramose, 2002 \& Bujo, 1998) clearly distinguish between European and African perspectives or understanding of death:

From the Euro-American perspectives, life is seen to be consisting of discreet stages, starting with conception and ending with death. Death, therefore, marks the end of life. On dying, the dead person ceases to exist. On the contrary, an African worldview understands death as an integrated and continuous developmental life process inseparable from the interwoven connections between the visible and invisible ontologies. People do not cease to exist once they are physically dead. Instead, they transcend to the spiritual world to live in the community of the living dead.

Therefore, for African societies, death is a continuation of life in another realm that differs from the Euro-American perspectives.

\section{How the Africanworldview understands death}

Appel (2011:45) posits that each society's beliefs and customs shape the cultural aspect of the response to death. Rituals are imperative in African traditional religion and need to be adhered to in some form (Masoga, 2012). Zungu (2021:7) mentions that the suppression of funeral rituals is traumatic and anxiety-inducing for family members determined to appease the 'living' dead and to keep them on a pedestal. They permeate all of life, from birth, puberty, and adulthood, to death. Mbiti (1971:26) posits that according to the African worldview, death stands between the world of human beings and the world of the spirits, between the visible and the invisible. It is no wonder, therefore, that rituals connected with death are elaborate and considered to be vitally important. Etim (2019:1) mentions that the subject of rituals shows that a human being is a homo faber (a working animal), homo religious (a religious being), homo loquen (a speaking being), homo symbolicus (a symbolic being). Kyalo (2013:35) further describes the nature and role of rituals when he says:

Rituals are symbolic, routine, and repetitive activities and actions through which we make connections with what we consider to be the most valuable dimension of life. They are often associated with significant events or places in our individual and communal lives. Rituals set aside specific times and places and provide us with an opportunity to ponder their meaning and to connect emotionally.

It should be noted that different communities in Southern Africa practice various bereavement rituals. However, despite the difference in ritual practices, the bottom line is that rituals are part and parcel of the African worldview. Biwul (1978:3) also mentions that Africans bury the dead according to their traditional cultural rituals. Zungu (2021:7) adds that, if this ritual is not performed, a dark cloud lingers over family members resulting in misfortunes befalling them until it is eventually performed as required by culture.

\section{Theoretical Framework}

The study is underpinned, first by the attachment and dual-process theory as a point of departure. The adopted attachment theory originates from John Bowlby and is founded on the premise that people develop bonds with each other; the theory originated from an interest in investigating cases of depression and mourning among children, as cases that arose from psychiatric and psychoanalytic thinking (Bowlby, 1980:216). Bowlby's theory stems from cognitive psychology and information theory that seeks to demonstrate the influences on responses of loss of the experiences which a bereaved person has had with attachment figures during the whole course 
of his or her life and especially during his or her infancy, childhood and adolescence (Bowlby, 1980:216).

A second theory is the dual-process model developed by Kohler (1930), who believed that perceptions and knowledge are never simply given to a perceiver by stimuli but are constructed by the perceiver (cited by Moskowitz, 1999:12). This theory was originally developed to deal with the loss of a partner (Stroebe \& Schut, 1999:211). The methodology employed illustrates how the two theories, as mentioned above, guided this study.

\section{Methodology}

Qualitative research was used to generate data guided andlnformed by a social constructivist/interpretivist paradigm. The study used a qualitative research approach to generate data in the descriptive, explorative case study which was undertaken. Within this paradigm, the attachment theory guided this study regarding human relationships, especially in understanding death effects on such attachments, while the dual-process theory clarified human reactions to different circumstances faced in life.

The population of this study comprised members of the Methodist Church of Southern Africa, who reside in Mamelodi, Pretoria. The target population was specifically those members who had recently experienced bereavement. Purposive sampling was used to select 25 bereaved people or families in line with this research objective.

In the thematic analysis, trends and patterns emerged from the collected data which ultimately led to themes being developed and verified, using a member check by the participants. Ethical considerations were considered to ensure that the process of research met all ethical requirements.

\section{Findings and interpretation of the results}

Okeke et al. (2017:1) argue that when two different religious systems exist in one community, the tendencies for conflicts of socioreligious, ideological, physical, and even political characters will arise between them. In this case, conflict refers to ideological battles, which often arise between the Christian and African traditional religious ideologies about issues such as inter alia death. This leads to the views raised by Etim (2019:1) who posits that African rituals, like other phenomena of African cultural heritage, are usually faced with criticisms of being either superstitious, a fetish, mundane or simply irrational. The main themes that emerged from the interviews and the focusgroup conversations now follow..

\section{The meaning of bereavement rituals for members of the Methodist Church in Mamelodi, Pretoria}

The findings of the research are that the church offers a lot to console the Christian aspect of the participants; however, the church seems not to be able to address their Africanness during the critical process of bereavement. For the participants, the church presently offers the necessary support, and also gives hope with regard to a loss. However, the church does not address the issues of sefifi, a mourning period, cleansing, ancestors, etc. Tshoba (2014:22) defines sefifi, and what causes itwhich implies a negative shadow, which also means that the family is thrown into a state of instability. Letsosa and Semenya (2011:1) further state that during the time of sefifi, the rights of the bereaved to perform certain duties in the community are reduced until such time that they are purified traditionally. Tshoba (2014:20) states that in traditional African societies, when a family member has died, the family of the deceased is regarded as soiled or polluted by contact with the dead. Broodryk (1997:180) states that African people seek solutions for their problems from the African perspective or worldview; whether the problems are of a material, spiritual, or 
social nature. Moyo (2013:221) states that Africans are very religious and in their religiosity still seeks solutions and direction from African traditional religions notwithstanding being Christian converts.

Four different perspectives emerged regarding what bereavement rituals meant for the participants who were interviewed. The themes included: rituals meant nothing; rituals were observed out of respect, culture, and identity. Some of the participants interviewed mentioned that bereavement rituals meant nothing to them, and that they did not even observe them.

Another perspective is that bereavement rituals were observed due to cultural requirements which people felt obliged to uphold. Amanze (2002:13) mentions that culture means the totality of people's way of life including their values, beliefs, aspirations, and modes of behaviour, which are learned and passed on within the group. This refers to the whole range of human activities learned and is not instinctive, and which is transmitted from generation to generation through various learning processes. Those who observed these rituals respected the deceased who believed and practised them while alive, and in some instances, the elders in the family believe in these rituals as well. Lastly, these rituals reflected their African-ness or identity as African people; hence they were regarded as key during their bereavement process and in coming to terms with their loss. Some participants observed these bereavement rituals since it is their culture. Bujo (1992:22) states that when the living conduct themselves according to the patterns recognized by the ancestors, they are strengthening the tribe or clan as a whole and are contributing to the welfare of each individual member. They observe the rituals because they appreciate what they mean for them and their loved ones. Amanze (2002:13) citing Lewis, 1976) states that culture is the protective shell of a community. Isaak (1997:72) notes that culture is about what we do today, as well as what our parents did yesterday.

\section{The significance of African traditional bereavement rituals}

The participants shared two perspectives regarding the importance of African traditional bereavement rituals. First, due to their Christian beliefs, a group stated they did not see any significance in African traditional bereavement rituals. To them, the Christian bereavement rituals that were observed were sufficient. Hence, the conclusion that some of these bereavement rituals meant nothing to them based on the teaching of the Christian faith. Therefore, they did not see any significance in the bereavement rituals at all (Mokhutso, 2019:63).

The second group of participants stated that African bereavement rituals did not mean much to them, because they were not raised in homes where such practices were performed in any case (Mokhutso, 2019:63).

\section{The significance of Christian bereavement rituals}

All the interviewed participants agreed that Christian bereavement rituals such as evening prayer services, preaching, and the singing of hymns and choruses were significant in their lives, especially during their time of mourning. When the church also ministers to those who grieve and consoles them in the funeral rites with the comforting word of God and the sacrament of the Eucharist (Order of Christian Funerals 1988:1). Therefore, performing traditional bereavement rituals alone and not involving their Christian faith were insufficient for them. As Christians, they could not do without the bereaved rituals that the church offers during this time. Those who believe in and practise both rituals justified this by stating that this is very significant, because they were both Africans and Christians (Mokhutso 2019:64).

\section{Reasons for combining African traditional and Christian bereavement rituals}

During the interviews, three perspectives emerged regarding the topic of understudy. First, one response was that a person belongs to a community that combines African traditionalists and 
Christian believers. Hence the two worldviews are embraced at the same time. Some stated when death occurs, no single person makes a decision (Mokhutso 2019:64). Finally, Turaki (1999:101) posits that a man is not an individual living in a state of independence in African thought, he is rather communal, living in a state of relationships and interdependence.

Secondly, some of the participants expressed views that correspond agree with Mokhutso (2019:64) In some cases, the deceased might not have believed in the traditional bereavement rituals but when they pass on, the surviving spouse or children, in some cases relatives, might choose which rituals will be observed during the bereavement process. Some practised this, because African bereavement rituals were practised within their families and among their relatives. For these participants, this is how they were used to doing things during bereavement. Thirdly, other participants observed the two bereavement rituals because they have observed and were taught in their families "...they grew up seeing these things happening in their own families as they grew up, and that is what they were exposed to when attending relative's funerals. Therefore, for them, it is what they have become accustomed to. It is something that they were taught, have observed, and have also passed on to their children" (Mokhutso 2019:65). Finally, Moyo (2013:221) states that Africans are very religious and, in their religiosity, still seek solutions and guidance from African traditional religions despite being Christian converts. This kind of research expresses that Christianity cannot respond to the care or needs of Africans by way of its Western-based pastoral care systems, whose challenges are at times based on African paradigm such as witchcraft. It would also be an infringement of basic human rights not to consider African perspectives on life and death issues in faith (See Onumah and Nicolaides, 2021).

\section{OBSERVATIONS AND RECOMMENDATIONS}

The following are the observations and findings of this study from the interviews conducted.

\section{Recognition of African Traditional religion}

The first observation from the interviews is that African traditional religion is a reality in many African peoples' lives, irrespective of other religious affiliations. The mainline or former missionary churches generally tend to ignore this reality, thus creating confusion among their members because of a lack of a point of reference from the church. Sigg et al. (2017:664), states that Christianity is not bound to the original culture of its founder; it expands through a process of translation, taking on the flavor of local cultures as it sinks its roots into different contexts. This study shows that the Christianity in the Methodist Church of Southern Africa still needs to expand and sink into the 'roots of Africa'. Adamo (2009:1) argues that it seems that Christianity in Africa has not adequately tapped this resource that can make Christianity authentically African. It is recommended that clear guidelines for the mainline or former missionary churches can help and guide members. There are conflicting understandings of what these rituals mean by different congregations who practise African traditional bereavement rituals. The role of the church is to teach and guide its members. Therefore, careful attention is needed to provide a helpful, and theologically sound guidance for members. The church can no longer ignore the reality of the need to be inculturated.

\section{Strengthening of Confirmation Classes}

During the interview, some of the participants could not fully articulate their theology or what the Methodist Church of Southern Africa stands for, especially regarding the dual practice of the Christian and African traditional bereavement rituals. Many could not share what the practices meant and their justification for the Methodist's Church doctrines and teachings. Therefore, it is recommended that the Methodist Church of Southern Africa strengthen its confirmation syllabus 
so that Methodists, wherever they find themselves, and in whatever they do, can discern which practices contradict their beliefs as Methodists, in order to fully articulate what they believe in. Hill (1963:138) argues that:

Teaching belongs to the essence of the church and a church that neglects this function of teaching has lost something that is indispensable to its nature as a church. It is a defective church if it is lacking at this point, just as a church in which the gospel ceases to be preached in its purity or a church in which the sacraments cease to be rightly administered is a defective church.

Teaching has always being part of the Methodist DNA from the work or early Methodists such as John and Charles Wesley and others who established schools from a lower level to the tertiary level. Charles Wesley $(1707$ - 1788) was the English leader of the Methodist movement. He maintained that teaching is an important ministry within the Methodist tradition which still exists and which needs the church to seriously reconsider in order to disciple its members about their faith and how to conduct themselves (Tomkins, 2003). After all it is in and through Confirmation, that those who have been baptized are able to declare their faith in Christ and are strengthened by the Holy Spirit for continuing discipleship in His church.

\section{Need for dialogue}

Serious dialogue is needed in Africanisation issues. Panikkar (1975:407) argues that religious dialogue means there must be an exchange of views and insights employing concepts expressed in words that are based on a previous agreement concerning their common understanding. The dialogue then tries to widen and deepen, to pinpoint divergences, similarities, complementarities, and criticisms, as well as to find the loci where mutual influence or fecundation may take place (Panikkar, 1975:407-409). Members of the Methodist Church of Southern Africa need to be guided and taught, and the church also needs to gradually embrace the good in the African knowledge system. That can only be possible if an open, honest dialogue takes place within the church. They are ignoring the presence of the African Indigenous knowledge system and this is invariably more detrimental than helpful. Not only detrimental to itself but its members as well. According to this study, there is the secrecy that goes with other traditional practices by Methodist members. Secrecy may mean many things like embarrassment or a feeling of guilt and thereby not wanting people to know something or other. That again leads to the Church members not being guided where necessary and they are unable to ask for guidance. As mentioned by Panikkar (1975:407), Dialogue brings that which is not known, understood, secretive to the open, and all parties learn out of that process.

\section{Additions to liturgy}

Generally, a deceased person may have left details of the sort of funeral that they hoped for. Ministers want to support families in keeping to such arrangements as much as possible and in making the service a personal and appropriate occasion but need to be cognisant of the African traditions which exist. Taking funerals is always important part of the minister's work and he or she will take time to visit families and needs to know how to treat people in their cultural milieu while seeking to offering comfort and support before and after the funeral itself. There are however various rituals to observe (Forster \& Bentley, 2008).

The participants shared that they have practised several rituals during the liturgy led by the church. Some African traditional bereavement rituals are practised in the process of bereavement. Before a body enters a household, in some instances a moment will be given to the family to say clan names, alerting the deceased that they have arrived home. The process is observed when the body leaves the homestead. Nonetheless, grieving is an accepted and important part of coming to terms with and healing a human loss and it may continue for several months or even 
years. There are people in most local churches who have experienced loss and they are often the best people to offer support in the months and years following a death but need to understand the African psyche and traditions of past generations in order to do so meaningfully.

Zungu (2021:6) refers to the body leaving the mortuary as ukulanda isidumbu which entails talking to the deceased using umlahlankosi (a buffalo thorn) branch. This practice takes place everywhere, even if the car stops at the traffic lights, if it is stuck in traffic, if it is crossing the river, he/she has to be informed (Zungu, 2021:6). Before a coffin is placed in the grave, families often cover the casket with a blanket, and other items. The challenge is that such practices are not clearly understood or even scrutinized as to whether they are in line with the teachings and doctrines of the Methodist Church of Southern Africa. Thus, the recommendation is for more research, guidelines, and inclusion of such practices in the Methodist Church of Southern Africa's funeral liturgy. The fact is that these practices already form part of the liturgy; they need to be formalized and theologized accordingly. This call is also made by scholars such as Adamo (2009:1) who informs the Christian community that there is an urgent need for dialogue between Christianity and African Indigenous Religion (AIR), because the present version of Christianity and the increase in membership of AIR is alarming. The missionary version of Christianity accepted by Africans can be described as being hypocritical, because many African Christians still patronize AIR, especially in times of emergency. This fact raised by (Adamo 2009:1) is seen in a rising number of African Initiated Churches.

\section{Need for further research}

This research attempted to show that most of the participants interviewed find value, healing, and closure in African traditional bereavement rituals. It is thus recommended that the church should do more research, in order to understand the meaning and impact of different bereavement rituals and to continue embracing and using those without conflicting the church's teachings and doctrines. The church remains a church in Africa, and it should use that which is helpful and meaningful to African people within the context of their culture and diverse traditions.

\section{Conclusion}

This study investigated what bereavement rituals mean to members of the Methodist Church of Southern Africa in Mamelodi, Pretoria, and whether any of these are in fact practised rituals or not. It also explored the significance of African traditional and Christian bereavement rituals. Lastly, this research examined why members of the Methodist Church practise both rituals concurrently. An African character in the church would not reject Christian teachings per se, but when things are done in a western way, this tends toplace black people at the fringes of society, devoid of their own inherent cultural systems. The philosophy of black consciousness asserts that the effects of the oppression of black people in South Africa must be redressed, and thus from a Christian perspective it is important to promote an indigenisation of Methodism to African contexts. After all the Wesleyan theology of mercy, is based on theon theology of Imago Dei, which sustains the dignity and value of all human beings. (Field, 2015).

The study found that not all Methodists practise African traditional bereavement rituals for several reasons which have been enumerated upon It also found that other than those who do not practise these rituals, there are some who do so, and this is due to mostly the elders interests or beliefs in the family or according to the deceased's last wishes. There are those who practise African traditional bereavement rituals openly and freely because they believe that this embraces who they are as Africans and Christian believers.

In addressing the main research question, the findings of this study showed evidence of different contestations among Methodists regarding African traditional bereavement rituals. MCSA does 
not have a clear liturgy or guidelinesfor its membersregarding African bereavement rituals or bereavement rituals in general.

Hence, the Methodist Church of Southern Africa and other mainline or former missionary churches need to pay attention to African traditional practices and to an extent need to indigenise their practices. Being quiet or ignoring this fact does not help church members. More teaching and research are also necessary regarding African traditional religious practices, which mainline churches embrace. This also calls for the mainline churches to strengthen their teachings about their beliefs, so that their members can discern which practices are helpful to their faith, irrespective of the norms in their families or communities based on tradition and culture.

\section{ACKNOWLEDGEMENTS}

I would like to thank Dr Pamela Makati from the University of the Free State Postgraduate School, for guiding me in the infant stages of this study, and Prof. Annette Wilkinson, for step-by-step guidance in this project.

This article is by no means written or influenced by any financial gain from any individual or institution.

\section{References}

Adamo, D.T. (2011). Christianity and the African traditional religion(s): The postcolonial round of engagement, Verbum et Ecclesia, 32(1), doi:10.4102/ ve.v32i1.285

Amanze, J.N. (Ed.). (2010). Biblical studies, theology, religion and philosophy: An introduction for African Universities, Eldoret: Zapf Clancery

Appel, D. L. (2011). Narratives on death and bereavement from three South African cultures. Unpublished Master of Psychology dissertation, Pretoria: University of South Africa.

Baloyi, L. \& Makobe-Rabothata, M. (2013). The African conception of death: A cultural implication. In L.T.B. Jackson., D. Meiring., F.J.R. van de Vijver., E.S. Idemoudia \& W.K. Gabrenya (Eds.), Towards sustainable development through nurturing diversity: Proceedings from the $21^{\text {st }}$ International Congress of the International Association for Cross-Cultural Psychology. [Available from: https://scholaworks.gvsu.edu/iaccp_papers/110/.] (Retrieved 09 July 2021).

Biwul, J.K.T. (1978). The African tradition of burial in the ancestral land and its implications for African Church today. [Available online at: https://tcnn.ng/wpcontent/uploads/2017/08/RB_Biwul.pdf] (Retrieved 09 July 2021).

Bowlby, J. (1980). Attachment and loss: Volume III: Loss, sadness and depression, New York: Basic Books.

Broodryk, J. (1997). Ubuntuism as a worldview to order society. Unpublished PhD dissertation. University of South Africa, Pretoria.

Bujo, B. (1998). The ethical dimension of community: The African model and the dialogue between North and South. Nairobi, Kenya: Pauline Publications Africa.

Davidsen-Nielsen, M. \& Leick, N. (1991). Healing pain: Attachment, loss and grief therapy, London: Routledge.

Etim, F. (2019). Ontology of African Ritual, Advances in Applied Sociology, 9, 1 - 14. [Available online at https://doi.org/10.4236/aasoci.2019.91001] (Retrieved 13 July 2021).

Field, D. N. (2015). Holiness, social justice and the mission of the church: John Wesley's insights in contemporary context. The Journal of Wesley House Cambridge, I(2), 177-198. 
Forster, D. \& Bentley, W. (2008). Methodism in Southern Africa: A celebration of Wesleyan Mission, Kempton Park: AcadSA publishers.

Hill J.W. (1963). The Teaching Ministry of the Church. Journal of Christian Education. 1963;os6(3),138-146. [doi:10.1177/002196576300600304] (Retrieved 16 July 2021).

Isaak, P.J. (1997). Religion and society: A Namibian perspective. Windhoek: Out of Africa Publishers

Keating, C. (2002). Death: A theological position Statement, Phoenix: Fuller Theological Seminary.

Ketshabile, K. (2012). Methodist burial rites: An inquiry into the enculturation of Christianity among Barolong of Mahikeng, South Africa. Unpublished PhD dissertation. Boston University: Boston.

Kumalo, S. (2018). A critical analysis of contesting theologies, liturgies and practices at the funeral of Methodist leaders, The new dimension, 47(11), 13.

Kyalo, P. (2013). Initiation rites and rituals in African cosmology. International Journal of Philosophy and Theology, 1(10), $34-46$.

Letsosa,R. \& Semenya, K. (2011). A pastoral investigation of the phrase 'go tlosa setshila' [traditional purification] as the last phase in the process of bereavement mourning amongst the Basotho, Verbum et Ecclesia, 32(1).

Lincoln, Y.S. \& Guba, E.G. (1985). Naturalistic inquiry, London: Sage Publications.

Makgahlela, M.W. (2016). The pschology of bereavement and mourning rituals in a Northern Sotho community. Unpublished PhD thesis. University of Limpopo: Polokwane.

Mandela, N. (2013) Address by President Nelson Mandela to the Annual Conference of the Methodist Church". ANC. 5 May 2013.

Masoga, M.A. (2012). A critical dialogue with Gabriel Molehe Setiloane: The unfinished business on the African divinity question, Studia Historiae Ecclesiasticae, 38(Suppl. 1), 1-13. Retrieved June 23,

Mbiti, J.S. (1971). African religion and philosophy. London: Heinemann Educational Books Ltd.

Mbiti, J.S. (1991). Introduction to African religion. $2^{\text {nd }}$ edition. Oxford: Heinemann International Literature and Textbooks.

Mbiti, J.S. (1993). Divinities, spirits, and the living dead. In R. Eastman (Ed.). The ways of religion: An introduction to the major traditions. $2^{\text {nd }}$ edition. Oxford: Oxford University Press.

McGrath, A.E. (2001). Christian theology: An introduction. $3^{\text {rd }}$ edition. Oxford: Blackwell Publishing.

Mokhutso, J. (2019). African Traditional Bereavement Rituals Amongst Methodist Church Members in Mamelodi, Pretoria. Unpublished Masters dissertation. University of the Free State, Bloemfontein.

Moyo, H. (2013). Religion and African Indigenous Knowledge Systems: Healing and Communal Reconstruction in African Communities. Alternation, Special Edition, (11) 207 - 236

Nicolaides, A.C. \& Willimus ,K. (2019). The Crucifixion of Christ in its milieu and its spiritual significance, Pharos Journal of Theology, 100. 
Nicolaides, A. (2014). The Seventh Ecumenical Council and the veneration of icons in Orthodoxy, Acta Theologica, 34 (2),

Nicolaides, A. (2005). 'Ubuntu promoting ethical business conducts in African Society. Orthodox and the great social and economic problems of Africa: The contribution of the great monotheistic to their solution', Paper presented at the International Interparliamentary Assembly on Orthodoxy Conference, University of Johannesburg, 02 December.

Ntombana, L. (2015). The trajectories of Christianity and African ritual practices: The public silence and the dilemma of mainline or mission churches. Acta Theologica, 35 (2): $104-119$.

Okeke, T.G., Ibenwa, C.N, \& Okeke, O.C, (2017). Conflicts Between African Traditional Religion and Christianity in Eastern Nigeria: The Igbo Example. SAGE Open. 1 - 10.

Onumah, J.M. \& Nicolaides, A. (2021). Human Rights and Eastern Orthodox Understanding and Teachings for a Troubled World, Pharos Journal of Theology, 102 (2021)

Order of Christian Funerals, Introduction English Translation. (1988). International Committee on English in the Liturgy, Inc. England and Wales.

Ramose, M.B. (2002). African philosophy though Ubuntu, Harare, Zimbabwe: Mond Books Publishers.

Sigg, M.M., Pascal, E.M. \& Zurlo, G.A. (2016). Indigenous and Vernacular Christianity. McClymond: John Wiley \& Sons, Ltd.

Stroebe, M. \& Schut, H. (1999). The dual process model of coping with bereavement: Rationale and description. Death Studies, 23(3), 197-224. [Available online at https://doi.org/10.1080/074811899201046] (Retrieved 13 July 2021).

Tomkins, S. (2003). John Wesley: A Biography, Oxford: Lion.

Tshoba, Z.M. (2014). The psychological significance of shaving hair as a ritual during mourning within the Ndebele culture. Unpublished master's dissertation. University of South Africa, Pretoria.

Turaki, Y. (1999). Christianity and African gods: A Method in theology. Potchefstroom: Potchefstroomse Universiteit.

Wood, W., Labrecque, J.S., Lin, P.Y. \& Runger, D. (2014). Habits in dual-process models in dual process of the social mind, New York: The Guilford Press.

Zungu, E.B. (2021). Juxtaposing adherence to COVID-19 regulations and practising proper burial rites: a case study of Zulu Traditional Religion, Pharos Journal of Theology, 102 (2). 